\title{
Türk Bankacılık Endüstrisinde Piyasa Yapısı ve Karlılık İlişkisi
}

\author{
Market Structure and Profitability Relationship in the Turkish Banking Industry \\ Gürkan ÇALMAŞUR' ${ }^{1}$ Hüseyin DAŞTAN²
}

\begin{abstract}
ÖZET
Bu çalışmanın amacı, 2001-2014 dönemi itibariyle Türk Bankacılık endüstrisinde faaliyet gösteren bankalar için piyasa yapısı ve karlılık arasındaki ilişkiyi literatürde öne sürülen beş hipotez ile test etmektir. Bu amacı gerçekleştirmek üzere 20012014 döneminde 42 bankaya ait panel verilerin kullanıldığı çalışmada, yapı-davranış performans, göreli-piyasa-gücü, etkin yapı: x-etkinliği, etkin yapı: ölçek etkinliği ve rahat yaşam hipotezleri genelleştirilmiş en küçük kareler yöntemiyle test edilmiştir. Sonuç olarak, endüstride yapı-davranışperformans, göreli-piyasa-gücü ve etkin yapı: ölçek etkinliği hipotezlerinin kısmen geçerli olduğu ve rahat yaşam hipotezinin ise güçlü bir biçimde geçerli olduğu tespit edilmiştir.
\end{abstract}

Anahtar Kelimeler: Etkinlik, Piyasa Yapısı, Karlılık, Türk Bankacılık Endüstrisi.

\section{Gíriş}

Türk bankacılık endüstrisi genel olarak mevduat bankaları ile kalkınma ve yatırım bankaları olmak üzere iki kategoride değerlendirilmektedir. Mevduat bankaları kendi içerisinde kamusal sermayeli bankalar, özel sermayeli bankalar, tasarruf mevduatı sigorta fonuna devredilen bankalar ve yabancı sermayeli bankalar olarak sınıflandırılmaya tabi tutulmuştur. Hali hazırda ilgili endüstride 3 kamusal sermayeli banka, 11 özel sermayeli banka, 1 tasarruf mevduatı sigorta fonuna devredilen banka, 19 yabancı sermayeli banka ve 13 kalkınma-yatırım bankasının içinde yer aldığı toplam 47 banka faaliyet göstermektedir. Türkiye'de finansal sektörün aktif büyüklüğünün \%86'sını oluşturan bankalar, 11223 şubeye sahip ve toplam 200886 personeli istihdam etmektedirler.

Piyasa yapısı, rekabet gücü ve sosyal refah ile bağlantılı olduğu için iktisat ve endüstriyel iktisat

\begin{abstract}
The objective of this study is to test five hypotheses that have been proposed in the literature on the relationship between market structure and profitability of the banks operating in the Turkish banking industry during the period of 2001-2014. To achieve this objective, 42 banks' panel data used in the study for the period of 2001-2014, structureconduct-performance, relative-market-power, efficient structure: $X$ efficiency, efficiency structure: scale efficiency and quiet life hypotheses are tested by performing generalised least squares regression. Consequently, it is determined that structureconduct-performance, relative-market-power and efficiency structure: scale efficiency hypotheses are firmly held and quiet life hypothesis is strongly held in the industry.
\end{abstract}

Keywords: Efficiency, Market Structure, Profitability, Turkish Banking Industry.

literatüründe dikkat çekmektedir. Literatürde ön plana çıkan piyasa yapısının iki potansiyel belirleyicisi olarak, firmaların etkinlik düzeylerindeki farklılıklar ile düzenleyici veya kurumsal giriş engelleri ön plana çıkmaktadır. Bankacılık endüstrisinde piyasa yapısının belirleyicileri iki sebepten ötürü önem arz etmektedir. Illk olarak, piyasa yapısı sadece bankacılık sisteminin rekabet gücünü değil aynı zamanda firmaların fon teminine ulaşma becerilerini ve bu sayede onların yatırımlarını etkilemektedir. İkinci sebep ise bankacılık sistemi yoğun bir şekilde düzenlendiği için yapılan bu düzenlemelerin piyasa yapısı üzerinde muhtemel etkilerini değerlendirmektir (Gonzalez, 2009: 736).

Banka karlıığı, bankacılık firmasının performansı ile yakından ilintili olması ve makro ekonomik istikrara olan katkısından dolayı finansal gelişmenin önemli bir bileşenidir. Firma düzeyinde büyük kapsamda daha yüksek bir getiri sağlanması banka kırılganlığını azaltır. Makro düzeyde ise artan karlılık 
ekonomik olarak büyüyen ve gelişen sürdürülebilir bir bankacılık endüstrisini meydana getirir. Bununla birlikte, bankacılık sisteminin aracılık görevinden dolayı elde edilen yüksek getiriler mevduat faiz oranlarının da daha yüksek olmasına sebep olur. $\mathrm{Bu}$ durum parasal otoritelerin bankacilık sistemini dengeli bir biçimde düzenlemelerinin sebeplerinden biridir (Osuagwu, 2014: 46).

Piyasa yapısının firmaların performansını etkileyebileceği fikri endüstriyel iktisat literatüründen gelmektedir. Bu kapsamda, bankacilık sisteminin performansı ve piyasa yapısı arasındaki ilişkiyi açıklayan birçok ampirik çalışma bulunmaktadır. Banka performansı ve piyasa yapısı arasındaki ilişkiyi açıklayan Piyasa Gücü (Market Power, MP) ve Etkin Yapı (Efficient Structure, ES) olmaküzere iki paradigma bulunmaktadır (Ayadi ve Ellouze, 2013: 345).

Karlılık ve piyasa yapısı arasındaki ilişkiyi açıklamada, MP hipotezlerinde piyasa gücünün karlılığın değişimine sebep olan temel değişken olduğu ifade edilmektedir. Yoğunlaşmış piyasalarda, piyasa eksiklikleri vardır. Bu eksiklikler, yüksek yoğunlaşmanın ortaya çıkardığı işbirliğinin ve bankacılıkta sık bir biçimde olan katı düzenlemelerin yol açtığı giriş-çıkış engellerinin sonucunda meydana gelebilir. Bu eksikliklerden dolayı firmalar tam rekabetten sapan eksik rekabet piyasalarında faaliyet gösterirler. Bu durum firmalara fiyatlar ve ücretler üzerinde baskı oluşturabilme yeteneğini sağlar. Böylece, fiyat belirleyebilen firmalar daha yüksek karlar elde edebilir. Piyasa yapısı değişkeni piyasa gücünü iyi temsil eden değişkendir. Bu yüzden, piyasa eksiklikleri piyasa gücü hipotezinin iki farklı türü olan Yapı-Davranış-Performans (SCP) ve GöreliPiyasa-Gücü (RMP) hipotezleri arasındaki farkı belirlemektedir (Punt ve Rooij, 1999: 2).

Bu iki farklı piyasa gücü teorisine karşılık kar ile hem yoğunlaşma hem de piyasa yapısı arasında pozitif ilişkinin olduğunu ifade eden yani pozitif kar yapı ilişkisini savunan iki etkin yapı teorisi vardır. Etkin Yapı hipotezinin X-Etkinliği (ESX) versiyonunda üstün yönetim ve üretim teknolojilerine sahip firmaların daha düşük maliyetli olacakları ve bu yüzden daha yüksek kar elde edecekleri iddia edilmektedir. Aynı zamanda bu firmaların büyük piyasa payı elde edecekleri ve böylelikle yoğunlaşma düzeylerinin artacağı da ifade edilmektedir. Burada ifade edilen pozitif kar-yapı ilişkisi etkinliğin hem karlara ve hem de piyasa payına dolaylı dönüşümünü belirtir. Etkin
Yapı hipotezinin ölçek etkinliği (ESS) versiyonunda ise firmalar eşit olarak iyi yönetim ve teknolojiye sahip olabileceği ama bazı firmaların üretim ölçeğinde diğer firmalardan daha etkin olması ve bu yüzden birim başına daha düşük maliyet ve birim başına daha yüksek karların elde edilebileceği ileri sürülmektedir (Berger, 1995: 404-405).

Iffade edilen iki piyasa gücü hipotezi ve iki etkin yapı hipotezinin firma birleşmeleri ve antitröst politikalar için farklı çıkarımları bulunmaktadır. Eğer etkin yapı hipotezi geçerliyse firma birleşmelerinin arka planında yatan neden üretici ve tüketici rantını arttıran etkinlik artışlarıdır. Diğer taraftan, piyasa gücü hipotezinin geçerli olması durumunda firma birleşmelerinin arkasında yatan neden hem tüketici ve hem de üreticilerin rantını azaltan monopolcü fiyat belirlemeleridir. Sonuç olarak, takip edilecek antitröst politikalar için bir çıkarım elde edilebilir (Chortareas vd., 2009: 3).

Tablo 1'de piyasa yapısı ve karlılık arasındaki ilişkileri açıklayan hipotezler ifade edilmektedir. Tablo 1'de de görüldüğü gibi MP paradigması başlı̆̆ı altında SCP hipotezi, RMP hipotezi ve Rahat Yaşam (Quiet Life, QL) hipotezi yer almaktadır. Ayrıca ES paradigması kendi içerisinde ESX ve ESS hipotezleri olmak üzere ikiye ayrılmaktadır.

Bu çalışmanın temel amacl, Türk bankacılık endüstrisi için, 2001-2014 dönemi itibariyle piyasa yapısı ve karlılık arasındaki ilişkiyi SCP, RMP, ESX, ESS ve QL hipotezleri çerçevesinde değerlendirmek ve ilgili hipotezlerin geçerliliğini analiz etmektir.

Bu çalışma, Türkiye'de daha önce konu ile ilgili yapılan Denizer (1997), Kasman (2001), Okumuş (2002), Günalp ve Çelik (2004), Sarıgül (2013), Ayaydın ve Karakaya (2014), Özcan ve Çiftçi (2015) çalışmalarından piyasa yapısı ve karlılık arasındaki ilişkiyi açıklayan rahat yaşam hipotezinin test edilmesi açısından farklılık göstermektedir. Ifade edilen çalışmalarda SCP, RMP, ESX ve ESS hipotezlerinin Türk bankacılık endüstrisindeki geçerliliği test edilmiştir. Bu çalışmada söz konusu dört hipotezden ayrı olarak QL hipotezinin de endüstrideki geçerliliğinin test edilmesi çalışmaya özgünlük katmaktadır.

Türkiye' de, finansal sektörün temelini bankacilık oluşturmaktadır. Çünkü, endüstri finansal kaynakların çok büyük bir bölümünü toplamakta ve kullandırmaktadır. Gelişmiş ülkelerdeki bankaların milyarlarca dolar zararla ve iflaslarla etkilendiği 2008 krizinden, 2000-2001 krizinde çok büyük 
olumsuzluklar yaşadığı ve buna bağlı olarak da yapısal reformlarını tamamladığı için küresel ekonomik krizden etkilenmemiştir (Afşar, 2011: 169). 2008 krizi sonrası örnek gösterilen Türk bankacılık endüstrisinin piyasa yapısı ve karlılığı arasındaki ilişkinin 2001 yılı sonrasında incelenmesi önem taşımaktadır.

Tablo 1: Piyasa Yapısı ve Karlılık Arasındaki İlişkiyi Açıklayan Hipotezler

\begin{tabular}{|c|c|c|}
\hline \multirow{3}{*}{$\begin{array}{l}\text { Piyasa Gücü } \\
\text { (Market } \\
\text { Power, MP) } \\
\text { Paradigması }\end{array}$} & $\begin{array}{l}\text { Yapı-Davranış- } \\
\text { Performans (Structure- } \\
\text { Conduct-Performance, } \\
\text { SCP) Hipotezi }\end{array}$ & $\begin{array}{l}\text { Bu hipotez, bankacılık endüstrisindeki yoğunlaşmanın } \\
\text { bankaların fiyatlandırma davranışlarını etkilediğini ve } \\
\text { bankaların piyasa gücünü arttırdıklarını ifade etmektedir. Yani, } \\
\text { yoğunlaşmış bankacılık sistemlerinde faaliyet gösteren her bir } \\
\text { banka daha yüksek karlar elde edebilir. }\end{array}$ \\
\hline & $\begin{array}{l}\text { Göreli-Piyasa-Gücü } \\
\text { (Relative-Market-Power, } \\
\text { RMP) Hipotezi }\end{array}$ & $\begin{array}{l}\text { Bu hipotezde, sadece büyük bankaların fiyatları } \\
\text { etkileyebileceğini ve karlarını arttırabileceğini savunmaktadır. }\end{array}$ \\
\hline & $\begin{array}{l}\text { Rahat Yaşam (Quiet Life, } \\
\text { QL) Hipotezi }\end{array}$ & $\begin{array}{l}\text { Bu hipotezde, bankacılık endüstri yapısı ve bankanın karlılığı } \\
\text { arasında istatistiki olarak önemli bir ilişki olmadığını ileri } \\
\text { sürmektedir. Yani, bankaların yönetiminin fiyatları ayarlaması } \\
\text { gelirlerini arttırabileceği ama daha yüksek etkinsizlik } \\
\text { düzeyinde bunun bankaların daha yüksek karlarına yol } \\
\text { açmayacağını, etkinlik üzerine daha az odaklandığını ifade } \\
\text { eder. }\end{array}$ \\
\hline \multirow{2}{*}{$\begin{array}{l}\text { Etkin Yapı } \\
\text { (Efficient } \\
\text { Structure, ES) } \\
\text { Paradigması }\end{array}$} & $\begin{array}{l}\text { Etkin Yapı: X-Etkinliği } \\
\text { (Efficient Structure-X- } \\
\text { Efficiency, ESX) Hipotezi }\end{array}$ & $\begin{array}{l}\text { Bu hipotez, daha etkin bankaların daha düşük maliyete sahip } \\
\text { oldukları için daha karlı olacağını ve böyle bankaların daha } \\
\text { yüksek piyasa payları kazanarak bankacılık endüstrisinin } \\
\text { yoğunlaşma düzeyinin daha yüksek olmasını etkilediklerini } \\
\text { düşünmektedir. }\end{array}$ \\
\hline & $\begin{array}{l}\text { Etkin Yapı: Ölçek Etkinliği } \\
\text { (Efficient Structure-Scale } \\
\text { Efficiency, ESS) Hipotezi }\end{array}$ & $\begin{array}{l}\text { Bu hipotezde ise daha büyük bankaların ölçek } \\
\text { ekonomilerinden daha düşük birim maliyetlere sahip olacağını } \\
\text { ve daha yüksek karlar elde edebileceğini vurgular. Bu bankalar } \\
\text { yüsek piyasa paylarına yol açtıkları için endüstrinin yüksek } \\
\text { yoğunlaşmasına sebep olur. }\end{array}$ \\
\hline
\end{tabular}

(Kaynak: Deltuvaite, 2010:51)

\section{LITERATÜR ÖZETI}

Literatürde bankacılık endüstrisinde piyasa yapısı ve karlılık arasındaki ilişkiyi inceleyen pek çok çalışmaya rastlamak mümkündür. Aşağıdaki tabloda ilgili çalışmalardan bazılarıyla ilgili bilgiler kronolojik sıralamaya göre verilmektedir. 
Tablo 2: Bankacılık Endüstrisinde Piyasa Yapısı ve Karlılık Arasındaki Illişkiyi Açıklayan Hipotezler Üzerine Yapılmış Bazı Çalışmalar

\begin{tabular}{|c|c|c|c|c|c|c|}
\hline \multirow{2}{*}{ Çalışma } & \multirow{2}{*}{ Kapsam } & \multicolumn{5}{|c|}{ Hipotezler } \\
\hline & & SCP & RMP & QL & ESX & ESS \\
\hline Smirlock (1985) & ABD (1973-1978) & - & $?$ & $?$ & + & $?$ \\
\hline Evanoff ve Fortier (1988) & ABD (1984) & + & $?$ & $?$ & + & $?$ \\
\hline Berger ve Hannan (1989) & 470 banka (1983-1985) & + & $?$ & $?$ & + & $?$ \\
\hline Molyneux ve Thorton (1992) & 18 Avrupa ülkesi (1986-1989) & + & $?$ & $?$ & $?$ & $?$ \\
\hline Molyneux ve Forbes (1995) & 18 Avrupa ülkesi (1986-1989) & + & $?$ & $?$ & - & - \\
\hline Berger (1995) & Amerika (1980-1989) & - & + & $?$ & + & - \\
\hline Goldberg ve Rai (1996) & 11 Avrupa ülkesi (1988-1991) & - & + & $?$ & + & - \\
\hline Denizer (1997) & Türkiye (1986-1992) & + & $?$ & $?$ & + & $?$ \\
\hline Berger ve Hannan (1997) & Amerika (1980-1985) & + & - & + & - & - \\
\hline Berger ve Hannan (1998) & Amerika (1980-1989) & $?$ & $?$ & + & $?$ & $?$ \\
\hline Maudos (1998) & İspanya (1990-1993) & - & $?$ & $?$ & + & $?$ \\
\hline Punt ve van Rooij (1999) & 8 Avrupa ülkesi (1992-1997) & + & - & - & + & - \\
\hline Demirgüç-Kunt ve Huizinga (1999) & 80 ülke (1988-1995) & + & $?$ & $?$ & $?$ & $?$ \\
\hline Abreu ve Mendes (2001) & 4 Avrupa B. ülkesi (1986-1999) & - & $?$ & $?$ & $?$ & $?$ \\
\hline Kasman (2001) & Türkiye (1988-1996) & - & + & $?$ & + & + \\
\hline Okumuş (2002) & Türkiye (1989-1995) & + & - & $?$ & + & - \\
\hline Jansen ve De Haan (2003) & 11 Avrupa B. ülkesi (1989-1997) & - & $?$ & $?$ & - & - \\
\hline Beck vd. (2003) & 8 Avrupa ülkesi (1998-2001) & - & + & $?$ & $?$ & $?$ \\
\hline Chirwa (2003) & Malavi (1970-1994) & + & $?$ & $?$ & $?$ & $?$ \\
\hline Günalp ve Çelik (2004) & Türkiye (1990-2000) & - & - & $?$ & + & $?$ \\
\hline Staikouras ve Wood (2004) & 13 Avrupa Birliği ülkesi & - & $?$ & $?$ & - & - \\
\hline Jeon ve Miller (2005) & Amerika (1976-2000) & - & + & $?$ & $?$ & $?$ \\
\hline Fernandez de Guevara vd. (2005) & 5 Avrupa ülkesi (1992-1999) & - & $?$ & $?$ & + & + \\
\hline Gonzalez (2005) & 69 ülke (1996-2002) & $?$ & $?$ & $?$ & + & + \\
\hline Atemkeng ve Nzongang (2006) & Kamerun (1987-1999) & + & $?$ & $?$ & $?$ & $?$ \\
\hline Athanasoglou vd. (2006) & 7 Avrupa ülkesi (1998-2002) & + & $?$ & $?$ & + & + \\
\hline Bektas (2006) & Kuzey Kıbrıs (1991-1997) & - & $?$ & $?$ & - & $?$ \\
\hline Park ve Weber (2006) & Kore (1992-2002) & + & $?$ & $?$ & + & $?$ \\
\hline Pasiouras ve Kosmidou (2007) & 15 Avrupa B. ülkesi (1995-2001) & - & $?$ & $?$ & $?$ & $?$ \\
\hline Athanasoglou vd. (2008) & Yunanistan (1985-2001) & - & $?$ & $?$ & $?$ & $?$ \\
\hline Claeys ve Vennet (2008) & 36 Avrupa ülkesi (1994-2001) & + & - & $?$ & $?$ & $?$ \\
\hline Flamini vd. (2009) & 41 Afrika ülkesi (1995-2006) & - & $?$ & $?$ & $?$ & $?$ \\
\hline Fu ve Heffernan (2009) & Çin (1985-2002) & + & + & - & + & + \\
\hline Chourtareas vd. (2009) & 9 Amerika ülkesi (1997-2005) & - & - & $?$ & + & + \\
\hline Deltuvaite (2009) & 160 ülke (1987-2007) & + & $?$ & $?$ & $?$ & $?$ \\
\hline Muharrami ve Matthews (2009) & Arap ülkeleri (1993-2002) & + & - & - & + & + \\
\hline Tregenna (2009) & Amerika (1994-2005) & + & + & $?$ & - & - \\
\hline Deltuvaite (2010) & OECD ülkeleri (1979-2007) & + & $?$ & $?$ & $?$ & $?$ \\
\hline Mensi ve Zouari (2010) & Tunus (1990-2005) & - & + & - & - & + \\
\hline Seelanatha (2010) & Sri Lanka (1977-2005) & - & - & $?$ & - & - \\
\hline Kasman vd. (2011) & Avrupa ülkeleri (1995-2006) & + & + & $?$ & + & + \\
\hline Mensi ve Zouari (2011) & Tunus (1990-2005) & - & $?$ & $?$ & + & $?$ \\
\hline Mirzaei vd. (2011) & 40 gelişmiş ülke (1999-2008) & - & - & $?$ & $?$ & $?$ \\
\hline Gajurel ve Pradhan (2011) & Nepal (2001-2009) & + & - & + & + & - \\
\hline Behname (2012) & OPEC ülkeleri (1995-2009) & - & - & $?$ & + & + \\
\hline Garza-Garcia (2012) & Meksika (2001-2009) & - & + & $?$ & - & - \\
\hline Ye vd. (2012) & Çin (1998-2007) & - & + & + & - & - \\
\hline Ayadi ve Ellouze (2013) & Tunus (1990-2009) & - & - & $?$ & + & - \\
\hline Kamau ve Were (2013) & Kenya (1997-2011) & + & + & - & - & - \\
\hline Sarıgül (2013) & Türkiye (2003-2012) & + & $?$ & $?$ & $?$ & $?$ \\
\hline Ayaydın ve Karakaya (2014) & Türkiye (2003-2011) & + & $?$ & $?$ & $?$ & $?$ \\
\hline Al-Jafari ve Alchami (2014) & Suriye (2004-2011) & - & $?$ & $?$ & $?$ & $?$ \\
\hline Dietrich ve Wanzenried (2014) & 118 ülke (1998-2012) & + & $?$ & $?$ & $?$ & $?$ \\
\hline Osuagwu (2014) & Nijerya (1980-2010) & - & $?$ & $?$ & $?$ & $?$ \\
\hline Özcan ve Çiftçi (2015) & Türkiye (2006-2013) & - & $?$ & $?$ & + & $?$ \\
\hline
\end{tabular}

Not: +, yapılan çalışmada ilgili hipotezin desteklendiğini, -, yapılan çalışmada ilgili hipotezin desteklenmediğini, ?, yapılan çalışmada hipotezin test edilmediğini göstermektedir. 


\section{YÖNTEM}

Çalışmada, performans üzerinde piyasa yapısı ve etkinliğin etkilerini analiz etmek için Berger ve Hannan (1998) tarafından önerilen ampirik çerçeveden faydalanılmıştır.

Berger ve Hannan (1998), SCP ve ES hipotezleri arasında etkinliğin de yer aldığı model için bir dizi test geliştirmiştir. SCP, RMP, ESX ve ESS hipotezlerini test etmek için dört hipotez testi bulunmaktadır. Geleneksel SCP hipotezi yani daha yüksek karların yoğunlaşmış piyasalarda anti rekabetçi fiyat düzenlemelerinin bir sonucu olarak ortaya çıktığı ilk hipotez değişmeden kalmıştır. Diğer bir hipotez, daha büyük piyasa paylarına sahip olan firmaların piyasa gücünü elde edeceği ve daha yüksek karlar kazanacağını ifade eden RMP hipotezidir. SCP ve RMP arasındaki fark RMP hipotezinin gerçekleşmesi için yoğunlaşmış piyasaların varlığına gerek duyulmamasıdır. Geriye kalan diğer iki hipotez ise daha büyük piyasa paylarının firmaların etkin bir biçimde faaliyetinin bir sonucu olduğunu ileri süren ES hipotezi ile ilgilidir. Bununla birlikte etkinlik iki bileşene ayrılmaktadır. ESX hipotezinde üstün yönetime sahip firmaların üretim sürecini daha düşük maliyetle gerçekleştirdiği ve sonuç olarak daha yüksek karlar elde ettikleri varsayılmaktadır. Ortaya çıkan daha yüksek piyasa payları aynı zamanda daha yüksekyoğunlaşmaya yol açmaktadır. ESS hipotezinde ise benzer üretim ve yönetim teknolojisine sahip firmaların farklı ölçek ekonomileri düzeyinde faaliyet gösterebilecekleri ifade edilmektedir. Optimal ölçek ekonomilerinde faaliyet gösteren firmalar daha düşük maliyetlere sahip olacak ve ortaya çıkan daha yüksek karlar daha yüksek piyasa yoğunlaşmasına sebep olacaktır. ES hipotezinin her iki versiyonu da piyasa yapısı ve kar arasındaki pozitif ilişkiye alternatif bir açıklama sağlamaktadır (Goldberg ve Rai, 1996: 749).

Beş hipotez içerisinden SCP hipotezinin geçerli olup olmadığı aşağıda ifade edilen 1 no.lu eşitlik yardımıyla test edilebilmektedir (Ye, vd., 2012: 346):

$$
\pi_{i t}=\beta_{0}+\beta_{1} C O N C_{t}+\beta_{2} M S_{i t}+\beta_{3} T E_{i t}+\beta_{4} S E_{i t}+\sum \beta_{j} Z_{i t}+\varepsilon_{i}^{1}
$$

1 no.lu eşitlikte yer alan $p_{i t}$, Aktif Karlııı̆ı (ROA), Özkaynak Karlıı̆̆ı (ROE) veya Net Faiz Marjı (NIM) gibi i bankasının t zaman dilimindeki karlılığını, $\mathrm{CONC}_{t^{\prime}} \mathrm{CR}_{4}$ veya Herfindahl-Hirschman indeksiyle hesaplanan $\mathrm{t}$ dönemindeki yoğunlaşma düzeyini, $M S_{i t^{\prime}}$ i bankasının t yılındaki piyasa payını, $T E_{i t}$ i bankasının t periyodundaki teknik etkinliğini, $S E_{i t}$, i bankasının t yılındaki ölçek etkinliğini, $Z_{i t}, \mathrm{i}$ bankasının t periyoduna ait kontrol değişkenlerini temsil eden vektörü ve $\boldsymbol{e}_{i}$ ise hata terimini ifade etmektedir.

ES hipotezinin geçerli olması için gerekli koşullardan biri piyasa yapısı ve etkinlik arasında pozitifilişkinin bulunmasıdır. Bu yüzden, parametreler itibariyle aşağıdaki fonksiyonel biçimler tahmin edilir (Seelanatha, 2010: 24).

$$
\begin{aligned}
& M S_{i t}=a_{1}+a_{2} T E_{i t}+a_{3} S E_{i t}+\varepsilon_{i}^{2} \\
& C O N C_{t}=b_{1}+b_{2} T E_{i t}+b_{3} S E_{i t}+\varepsilon_{i{ }_{i}}^{3}
\end{aligned}
$$

Eğer piyasa yapısı ve etkinlik arasında kesin bir ilişki söz konusuysa yani etkin firmaların piyasa payı elde ettikleri ve aynı zamanda daha yüksek yoğunlaşmaya sahip oldukları varsayılıyor ise 2 ve 3 no.lu denklemlerdeki etkinlik değişkenlerine ait katsayıların pozitif işaretli olması gerekmektedir. RMP hipotezini desteklemek için ilave ilişkileri test etmek de mümkündür (Goldberg ve Rai, 1996: 750-751):

$$
\begin{aligned}
& T E_{i t}=c_{1}+c_{2} \operatorname{CONC}_{t}+c_{3} M S_{i t}+\sum c_{i} Z_{i t} \\
& S E_{i t}=d_{1}+d_{2} \operatorname{CONC}_{t}+d_{3} M S_{i t}+\sum_{i=1}^{n} d_{i} Z_{i t}+\varepsilon_{i}^{5}
\end{aligned}
$$

Tablo 1'de ifade edilen beş hipotezin (SCP, RMP, ESX, ESS ve QL) geçerli olması için gerekli koşullar tablo 3'de verilmektedir. Tablo 3'te de görüldüğü gibi, SCP hipotezinin geçerli olabilmesi için 1 no.lu eşitlikteki $b_{1}$ katsayısının pozitif ve 3 no.lu eşitlikteki $b_{2}$ ve $b_{3}$ katsayılarının sıfıra eşit olması gerekmektedir. Yine, RMP hipotezinin geçerli olması için 1 no.lu eşitlikteki $b_{2}$ katsayısının pozitif ve 2 no.lu eşitlikteki $a_{2}$ ve $a_{3}$ katsayılarının sıfıra eşit olması gerekmektedir. QL hipotezinin geçerliliği ise 4 no.lu eşitlikteki $C_{2}$ ve $C_{3}$ katsayıları ile 5 no.lu eşitlikteki $d_{2}$ ve $d_{3}$ katsayılarının sıfırdan küçük olmasıyla mümkündür. ESX hipotezinin geçerli olması için 1 no.lu eşitlikteki $b_{3}$ katsayısı ile 2 no.lu eşitlikteki $a_{2}$ ve 3 no.lu eşitlikteki $b_{2}$ katsayılarının pozitif olması gerekmektedir. Ayrıca, ESS hipotezi 1 no.lu eşitlikteki $b_{4}$ katsayısı ile 2 no.lu eşitlikteki $a_{3}$ ve 3 no.lu eşitlikteki $b_{3}$ katsayılarının sıfırdan büyük olmaları halinde geçerlidir. 
Tablo 3: Beş Hipotezin Geçerliliği İçin Gerekli Koşullar

\begin{tabular}{|l|c|}
\hline Hipotez & Koşullar \\
\hline Yapı-Davranış-Performans (SCP) & $b_{1}>0$ ve $b_{2}, b_{3}=0$ \\
\hline Göreli Piyasa Gücü (RMP) & $b_{2}>0$ ve $a_{2}, a_{3}=0$ \\
\hline Rahat Yaşam (QL) & $c_{2}, c_{3}, d_{2}, d_{3}<0$ \\
\hline Etkin Yapı: X-Etkinliği (ESX) & $b_{3}, a_{2}, b_{2}>0$ \\
\hline Etkin Yapı: Ölçek Etkinliği (ESS) & $b_{4}, a_{3}, b_{3}>0$ \\
\hline
\end{tabular}

(Kaynak: Ye vd., 2012: 347)

Bu çalışmada iki aşamalı bir yöntem uygulanmıştır. Illk aşamada yoğunlaşmayı ifade eden CONC, teknik etkinliği simgeleyen TEve ölçek etkinliğini gösteren SE değişkenlerinin değerleri elde edilmiştir. İkinci aşamada ise söz konusu beş hipotezin geçerliliği Genelleştirilmiş En Küçük Kareler yöntemi ile analiz edilmiştir.

Çalışmada yoğunlaşmayı ifade eden CONC değişkeni, Herfindahl-Hirschman indeksi yardımıyla hesaplanmıştır. Herfindahl-Hirschman indeksi, aşağıdaki gibi formülize edilebilmektedir (Pepall vd., 2005: 49).

$$
\boldsymbol{H}=\sum_{i=1}^{N} P_{i}^{2}
$$

$\mathrm{N}$ endüstrideki firma sayısını, $\mathrm{Pi} 2$ ise i. firmanın piyasa payının karesini göstermek üzere, HerfindahlHirschman indeksinin en yüksek değeri 1, en düşük değeri ise 1/N'dir. İndeks, 0 ile 1 arasında değerler almaktadır. İndeks değeri 1'e yaklaştıkça yoğunlaşma yükselmektedir. (Martin, 1988: 102). Çalışmamızda, $\mathrm{s}$, i. bankanın t yılındaki toplam aktiflerini, j, t zaman diliminde bankacılık endüstrisindeki toplam aktifleri ve $\mathrm{n}$ ise $\mathrm{t}$ dönemindeki toplam banka sayısını gösterdiği aşağıdaki formül yardımıyla daha kapsamlı Herfindahl-Hirschman indeksi hesaplanmıştır:

$$
H H I=\sum_{i}^{n}\left(\frac{s}{j}\right)^{2}
$$

Çalışmada teknik etkinlik ve ölçek etkinliğini elde etmek için Veri Zarflama Analizi (VZA) yaklaşımından faydalanılmıştır. VZA, Charnes, Cooper ve Rhodes tarafından 1978 yılında benzer mal veya hizmet üreten ekonomik karar verme birimlerinin göreli etkinliklerinin ölçülmesi amacı ile geliştirilen doğrusal programlama esaslı bir yöntemdir (Banker, 1992: 74).

Çalışmada etkinliğin doğrudan hesaplanan ölçütü kullanılmıştır. Daha önce Okumuş (2002) da etkinliğin doğrudan ölçütü için VZA yönteminden faydalanırken Günalp ve Çelik (2004) ise etkinliğin doğrudan ölçütü olarak Stokastik Sınır Yaklaşımından faydalanmıştır.

Etkinlik ölçümü için, Rasyo (Oran) analizi ve Sınır etkinliği analizi yöntemleri kullanılmaktadır. Sınır etkinliği analiz yöntemleri ise kendi içerisinde parametrik ve nonparametrik olmak üzere ikiye ayrılabilir. Parametrik yöntemler arasında Stokastik Sınır Yaklaşımı, Serbest Dağılım Yaklaşımı ve Kalın Sınır Yaklaşımı yöntemleri yer almaktadır. Nonparametrik yöntemler arasında ise genel olarak Veri Zarflama Analizi ve Serbest Atılabilir Zarf yöntemi bulunmaktadır. Çalışmada kullanılan VZA yönteminin en önemli avantajlarından biri girdiler ve çıktılar arasındaki üretim ilişkisinin fonksiyonel formu üzerinde sınırlamalara yer vermemesidir. Dahası, VZA, çoklu girdilere ve çoklu çıktılara aynı zamanda (eş anlı) uygulanabilmektedir. VZA, parametrik yöntemlerde olduğu gibi girdi ve çıktı arasında fonksiyonel bir ilişkiye intiyaç duymamakta, homojen olan birimler kendi aralarında mukayese edilebilmekte, girdi ve çıktı birimleri değişik birimlere (fiziksel üretim, parasal büyüklük, hatta rasyolar cinsinden) sahip olabilmektedir.VZA'da kararverme birimleri doğrudan diğer bir karar verme birimi ile ya da bu birimlerin değişik kombinasyonları ile karşılaştırılabilmektedir. Ayrıca, yöntem etkin olmayan karar verme birimlerinin nasıl etkin duruma getirilebileceği hakkında önemli ipuçları vermektedir. (Kalirajan ve Shand, 1999: 167; Ekren ve Emiral, 2002: 19; İnan, 2000: 86-88). Ifade 
edilen bu avantajlarından ötürü çalışmada etkinlik ölçümü için VZA yönteminden faydalanılmıştır.

VZA modelleri; CCR ve BCC modelleri olmak üzere iki grupta incelenebilmektedir. 1978 yılında Charnes vd. tarafından önerilen CCR modelinin temel özelliği, her bir karar verme biriminin çok sayıda çıktı ve çok sayıda girdi kullandığı durumu tek bir gözlemlenen girdi ve tek bir gözlemlenen çıktının bulunduğu yapıya indirgemesidir. Sembolik olarak, CCR modeli aşağıdaki şekilde yazılabilmektedir (Charnes vd., 1997: 40).

$$
\max h_{0}(u, v)=\frac{\sum_{r} u_{r} y_{r 0}}{\sum_{r} v_{i} x_{i 0}}
$$

Burada $u_{r}$ ve $v_{i}^{\prime}$ ler ağırlıklar, $y_{r o}$ ve $x_{i 0}{ }^{\prime} l a r$ ise sırası ile gözlemlenmiş çıktılar ve girdilerdir. Girdi odaklı BCC modeli, $n$ tane KVB 'ın ( $o=1, \ldots, n$ ) etkinliğini, aşağıdaki doğrusal programlama modelini çözerek hesaplamaktadır (Sueyoshi, 1992: 144):

Min: $\theta$ B

Așağıdaki kısıtlar altında:

$\theta_{B x o}-X \lambda \geq 0$

$Y \lambda \geq y_{0}$

$e \lambda=1$

$\lambda \geq 0$

$\theta_{B}$ : skalar değer

CCR ve BCC modelleri hem girdi ve hem de çıktı odaklı analiz yapma imkanına sahiptir. Çalışmada kullanılan TE ve SE değişkenlerini tespit etmek için CCR ve BCC modelleri ayrı ayrı tahmin edilmiştir. CCR modelinden elde edilen etkinlik değerleri TE değişkenini ifade ederken CCR modelinden bulunan teknik etkinlik değerinin $\mathrm{BCC}$ modelinden elde edilen teknik etkinlik değerine oranı ise SE değişkenini ifade etmektedir. İlgili modellerin tahmininde çıktı değişkenleri olarak, toplam kredi ve toplam mevduat girdi değişkenleri olarak ise toplam aktifler, şube sayısı ve personel sayısı kullanılmıştır. Banka girdi ve çıktılarının ölçülmesinde iki ayrı yaklaşım kullanılmaktadır. Bunlar üretim (production) ve aracılık (intermediation) yaklaşımları olarak ifade edilmektedir (İnan, 2000: 87). Çalışmamızda girdi ve çıktıların ölçülmesinde üretim yaklaşımından faydalanılmıştır. Bu çalışmada kullanılacak girdi ve çıktılara karar vermek için, literatürdeki konu ile ilgili çalışmalarda kullanılmış olan girdi ve çıktılar incelenmiştir. $\mathrm{Bu}$ inceleme neticesinde yaygın bir biçimde kullanılan girdi ve çıktı değişkenleri tespit edilmiştir. Girdi odaklı CCR ve BCC modelleri Timothy James Coelli tarafından geliştirilen DEAP 2.1 paket programı ile analiz edilmiştir.

Çalışmanın ikinci aşamasında piyasa yapısı ve karlılık arasındaki ilişkiyi analiz etmek için ilgili beş hipotezin geçerliliğinin testi genelleştirilmiş en küçük kareler yöntemi yardımıyla belirlenmiştir. Genelleştirilmiş En Küçük Kareler Panel Veri Modeli tahminleri ise Eviews 8.1 paket programıla tespit edilmiştir.

\section{VERILER ve DEĞişKENLER}

Bu çalışmada kullanılacak bağımlı ve bağımsız değişkenlere ait veriler, her yıl düzenli bir biçimde Türkiye Bankalar Birliği tarafından yayınlanan Bankalarımız Kitabı adlı istatistiki raporlardan ve TÜiK web sitesinden temin edilmiştir. Il gili veri seti, çalışmamızın zaman dilimi olarak ifade edilen 2001-2014 döneminde faaliyet gösteren 42 bankayı içermektedir.

2001 yılı Türk bankacılık endüstrisi için bir yapısal dönüşüm sürecinin başlangıç noktası olarak kabul edilmektedir. Bu yüzden, analizler için başlangıç yılı 2001 yılı olarak belirlenmiştir. Bu çalışmada piyasa yapısı ve karlılık arasındaki ilişkinin analiz edilmesinde kullanılacak bağımlı ve bağımsız değişkenler, literatürdeki çalışmalardan faydalanarak belirlenmiş̧ir. Literatür ışığında çalışmada kullanılan değişkenler, ilgili değişkenlerin tanımları ve değişkenlere ait tanımlayıcı istatistikler tablo 4 'te verilmektedir. 
Tablo 4: Tanımlayıcı İstatistikler

\begin{tabular}{|l|l|c|c|}
\hline Değişken & Tanım & Ortalama & Standart Sapma \\
\hline ROA & Aktif Karlılığı (Net Kar / Toplam Aktifler) & 0.015 & 0.092 \\
ROE & Özkaynak Karlıı̆ı (Net Kar / Toplam Özkaynaklar) & 0.053 & 0.891 \\
MS & Bankanın Toplam Aktif payı & 0.023 & 0.041 \\
CONC & Toplam Aktifler İtibariyle Herfindahl-Hirschman İndeksi & 0.096 & 0.005 \\
TE & Teknik Etkinlik (CCR Modelinden Elde Edilen) & 0.656 & 0.314 \\
SE & Ölçek Etkinliği (CCR Modeli TE / BCC Modeli TE) & 0.746 & 0.321 \\
ASSET & Bankanın Toplam Aktiflerinin Doğal Logaritmesı & 3.314 & 1.033 \\
LOAN & Bankanın Kredi ve Mevduatlarının Doğal Logaritması & 3.052 & 1.394 \\
RISK & Bankanın Kredi ve Mevduatları / Bankanın Toplam Aktifleri & 0.815 & 0.549 \\
AGE & Bankanın Yaşı & 35.119 & 28.988 \\
GDP & Reel Gayrisafi Yurtiçi Hasıladaki Büyüme Oranı & 4.171 & 4.637 \\
\hline
\end{tabular}

Tablo 4'te yer alan ROA ve ROE değişkenleri karlılığı temsil etmek için kullanılmıştır. Benzer biçimde MS değişkeni piyasa payını, CONC değişkeni yoğunlaşmayı, TE değişkeni teknik etkinliği, SE değişkeni ölçek etkinliğini ifade etmektedir. Geriye kalan ASSET, LOAN, RISK, AGE ve GDP değişkenleri ise kontrol değişkenleri olarak düşünülmüştür.
Tablo 5'te değişkenler arasındaki korelasyon katsayıları yer almaktadır. Tablodan da görüldüğü gibi, ASSET ile LOAN değişkenleri arasında yüksek bir korelasyon (0.933) olduğu görülmektedir. İlgili değişkenler arasında yüksek korelasyon olmasına rağmen banka karlıığı üzerinde değişkenlerin farklı etkileri oldukları düşünülmektedir.

Tablo 5: Bağımlı ve Bağımsız Değişkenler Arasındaki Korelasyon Katsayıları Matrisi

\begin{tabular}{|l|c|c|c|c|c|c|c|c|c|c|}
\hline & ROA & ROE & MS & HHI & TE & SE & ASSET & LOAN & RISK & AGE \\
\hline ROE & 0.319 & & & & & & & & & \\
\hline MS & 0.003 & 0.037 & & & & & & & & \\
\hline HHI & -0.108 & -0.073 & 0.002 & & & & & & & \\
\hline TE & 0.017 & 0.005 & 0.378 & -0.033 & & & & & & \\
\hline SE & 0.002 & 0.009 & 0.265 & 0.005 & 0.221 & & & & & \\
\hline ASSET & 0.076 & 0.061 & 0.714 & -0.263 & 0.639 & 0.555 & & & & \\
\hline LOAN & 0.046 & 0.048 & 0.645 & -0.207 & 0.602 & 0.735 & 0.933 & & & \\
\hline RISK & 0.177 & 0.038 & 0.273 & -0.112 & 0.698 & 0.625 & 0.434 & 0.602 & & \\
\hline AGE & 0.044 & 0.043 & 0.705 & -0.114 & 0.297 & 0.220 & 0.604 & 0.537 & 0.176 & \\
\hline GDP & 0.055 & 0.103 & -0.004 & -0.167 & -0.051 & -0.032 & 0.027 & 0.027 & 0.038 & 0.006 \\
\hline
\end{tabular}

\section{AMPIRIK BULGULAR}

Bu bölümde, 2001-2014 zaman dilimi içerisinde piaysa yapısı ve karlıık arasıdaki ilişkiyi tespit etmek amacıyla kullanılan eşitliklerden elde edilen tahmin sonuçları yer almaktadır. Ayrıca, tüm yıllarda faaliyet gösteren bankalara ait hesaplanan teknik etkinlik ve ölçek etkinliği değerleri de bu bölümde ele alınmıştır.

Tablo 6'da, VZA yardımıyla ölçeğe göre sabit getiri varsayımı altında elde edilen teknik etkinlik skorları ve ölçeğe göre değişen getiri varsayımı altında elde edilen teknik etkinlik skorları ile ölçek etkinliği değerleri yorumlanmıştır. Tabloda CCR etkinliği; Charnes, Cooper ve Rhodes'in geliştirmiş olduğu ölçeğe göre sabit getiri varsayımı altında hesaplanan etkinlik değerini, BCC etkinliği; Banker, Charnes ve Cooper tarafından geliştirilen ölçeğe göre değişen getiri varsayımı altında hesaplanan etkinlik değerini ve Ölçek etkinliği ise $C C R$ etkinlik değerinin $B C C$ etkinlik değerine bölünmesiyle elde edilmektedir. 
Tablo 6: 2001-2014 Dönemi İtibariyle Ortalama CCR, BCC ve Ölçek Etkinliği Değerleri

\begin{tabular}{|c|c|c|c|c|c|c|c|}
\hline Yıllar & $\begin{array}{c}\text { CCR } \\
\text { Etkinliği }\end{array}$ & $\begin{array}{c}\text { BCC } \\
\text { Etkinliği }\end{array}$ & $\begin{array}{c}\text { Ölçek } \\
\text { Etkinliği }\end{array}$ & Yıllar & $\begin{array}{c}\text { CCR } \\
\text { Etkinliği }\end{array}$ & $\begin{array}{c}\text { BCC } \\
\text { Etkinliği }\end{array}$ & $\begin{array}{c}\text { Ölçek } \\
\text { Etkinliği }\end{array}$ \\
\hline $\mathbf{2 0 0 1}$ & 0.656 & 0.905 & 0.739 & 2008 & 0.633 & 0.890 & 0.729 \\
\hline $\mathbf{2 0 0 2}$ & 0.626 & 0.899 & 0.710 & 2009 & 0.676 & 0.905 & 0.760 \\
\hline $\mathbf{2 0 0 3}$ & 0.662 & 0.892 & 0.750 & 2010 & 0.724 & 0.910 & 0.806 \\
\hline $\mathbf{2 0 0 4}$ & 0.666 & 0.884 & 0.772 & 2011 & 0.633 & 0.886 & 0.734 \\
\hline $\mathbf{2 0 0 5}$ & 0.635 & 0.895 & 0.723 & 2012 & 0.672 & 0.902 & 0.759 \\
\hline $\mathbf{2 0 0 6}$ & 0.630 & 0.917 & 0.703 & 2013 & 0.666 & 0.911 & 0.746 \\
\hline $\mathbf{2 0 0 7}$ & 0.626 & 0.903 & 0.710 & 2014 & 0.690 & 0.945 & 0.739 \\
\hline Ort. & 0.656 & 0.903 & 0.740 & Ort. & 0.656 & 0.903 & 0.740 \\
\hline
\end{tabular}

Tablo 6'dan da görüldüğü gibi yıllar itibariyle bankaların CCR, BCC ve Ölçek etkinliği değerleri farklılıklar göstermekle birlikte CCR etkinliği ortalama 0.656 , BCC etkinliği ortalama 0.903 ve ölçek etkinliği ise ortalama 0.740 'dır.

Illgili hipotezlerin geçerliliğini araştırmak için genelleştirilmiş en küçük kareler panel veri analizi kullanılmıştır. Panel veri analizinde, sabit etkiler veya rassal etkiler modellerinden hangisinin geçerli olduğuna karar vermek için Hausman testi yapılmakta ve model parametreleri arasındaki farkın istatistiksel açıdan anlamlı olup olmadığı incelenmektedir. Hausman testi istatistiği, "Rassal Etkiler Tahmincisi Doğrudur" sıfır hipotezi altında gerçekleşmektedir (Nerlove, 2005: 36). Tablo 7' de yer alan Hausman test sonuçları incelendiğinde, ROA değişkenin bağımlı değişken olduğu 1 no.lu eşitlikte, 2 no.lu eşitlikte, 4 no.lu eşitlikte ve 5 no.lu eşitlikte olasılık sıfıra çok yakın olduğundan dolayı HO hipotezi reddedilmiştir. Yani, söz konusu eşitlikler için sabit etkiler modeli daha uygundur. Diğer eşitlikler için ise rassal etkiler modelinin daha uygun olduğuna karar verilmiştir.

Tablo 7: Eşitlikler İçin Hausman Test Sonuçları

\begin{tabular}{|l|c|c|c|c|}
\hline Regresyon & $\begin{array}{c}\text { Test } \\
\text { Istatistiği }\end{array}$ & $\begin{array}{c}\text { Serbestlik } \\
\text { Derecesi }\end{array}$ & Olasılık & Sonuç \\
\hline ROA ile Diğer Değişkenler Arasında & 75.169 & 9 & 0.000 & Sabit Etkiler \\
ROE ile Diğer Değişkenler Arasında & 4.529 & 9 & 0.873 & Rassal Etkiler \\
MS ile TE ve SE Arasında & 15.868 & 2 & 0.002 & Sabit Etkiler \\
CONC ile TE ve SE Arasında & 2.820 & 2 & 0.244 & Rassal Etkiler \\
TE ile Diğer Değişkenler Arasında & 60.497 & 7 & 0.000 & Sabit Etkiler \\
SE ile Diğer Değişkenler Arasında & 45.705 & 7 & 0.000 & Sabit Etkiler \\
\hline
\end{tabular}

Tablo 8'de çalışmanın metodoloji kısmında ifade edilen 1 no.lu eşitlik banka karlıığını ifade eden ROA ve ROE değişkenlerinin bağımlı değişkenler olduğu iki modelin tahmin sonuçları görülmektedir. Her iki modelde de $R^{2}$ değerleri oldukça düşük olmasına rağmen modeller bir bütün olarak anlamlıdır ( $F$ istastiklerine ait $\mathrm{p}<0.05)$. ROA değişkeninin bağımlı değişken olduğu modelde $b_{1}$ katsayısı $\% 5$ önem düzeyinde istatistiki açıdan anlamlı ve pozitif işaretli olarak tahmin edilmiştir (0.412). Yani, yoğunlaşmanın artması ile karlıı̆ı̆ı olumlu yönde etkilemektedir. Buna göre, ilgili zaman dilimi içerisinde SCP hipotezinin kısmen geçerli olduğunu ifade etmek mümkündür. Bu sonuç, Türk bankacılık endüstrisi için daha önce yapılmış olan Denizer'in (1997), Okumuş'un (2002), Sarıgül'ün (2013), Ayaydın ve Karakaya'nın (2014) çalışmalarıyla paralellik göstermekte ve Kasman'ın (2001), Günalp ve Çelik'in (2004), Özcan ve Çiftçi'nin (2015) çalışmalarıyla ise farklılık göstermektedir.

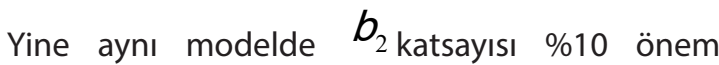
düzeyinde istatistiki açıdan anlamlı ve pozitif işaretli olarak tahmin edilmiştir (0.206). Yani, piyasa payının artması karlıığı arttırmaktadır. Bu sonuç 
ise RMP hipotezinin kısmen geçerli olduğunu temsil etmektedir. Yine, bu sonuç Kasman'ın (2001) çalışmasıyla paralellik göstermekte ve Okumuş'un (2002), Günalp ve Çelik'in (2004) çalssmalarıla farklılık göstermektedir. Ayrıca modelde ${ }_{3}$ katsayısı \%10 önem düzeyinde istatistiki açıdan anlamlı ve negatif işaretli olarak tahmin edilmiştir (-0.026). Bu sonuca göre, teknik etkinliğin artması karlılığı olumsuz yönde etkilemektedir. Bu durum, ESX hipotezinin ilgili modelde geçerli olmadığını ifade etmektedir. Bu sonuç, Denizer'in (1997), Kasman'ın (2001), Okumuş'un (2002), Günalp ve Çelik'in (2004),
Özcan ve Çiftçi'nin (2015) çalışmalarıyla farklılık göstermektedir. Modelde $\hat{b}_{4}$ katsayısı istatistiki açıdan anlamsız ve pozitif işaretli olarak tahmin edilmiştir (0.010). Teorik olarak ele alındığında ESS hipotezinin kısmen geçerli olduğunu söylemek mümkündür. Bu sonuç, Kasman'ın (2001) çalışmasıyla paralellik ve Okumuş'un (2002) çalışmasıyla ise farklılık göstermektedir. Kontrol değişkenlerinden RISK ve GDP değişkenleri ile ROA arasında pozitif, LOAN değişkeni ile ROA arasında ise negatif yönde ve istatistiki bakımdan anlamlı bir ilişki olduğu belirlenmiştir.

Tablo 8: Karlılık ile Yoğunlaşma, Piyasa Payı, Teknik Etkinlik, Ölçek Etkinliği ve Kontrol Değişkenleri Için Regresyon Sonuçları

\begin{tabular}{|c|c|c|c|c|c|c|c|}
\hline \multirow{2}{*}{ Değişken } & \multirow{2}{*}{ Katsayı } & \multicolumn{3}{|c|}{$\begin{array}{c}\text { Bağımlı Değişken } \\
\text { ROA }\end{array}$} & \multicolumn{3}{|c|}{$\begin{array}{c}\text { Bağımlı Değişken } \\
\text { ROE }\end{array}$} \\
\hline & & Değer & $\begin{array}{c}\text { Standart } \\
\text { Hata }\end{array}$ & Olasılık & Değer & $\begin{array}{c}\text { Standart } \\
\text { Hata }\end{array}$ & Olasılık \\
\hline Sabit & $b_{0}$ & $-0.087^{* *}$ & 0.033 & 0.010 & -0.366 & 0.513 & 0.475 \\
\hline CONC & $b_{1}$ & $0.412^{* *}$ & 0.204 & 0.044 & 1.216 & 3.035 & 0.688 \\
\hline MS & $b_{2}$ & $0.206^{* * *}$ & 0.107 & 0.054 & $1.415^{* * *}$ & 0.833 & 0.089 \\
\hline TE & $b_{3}$ & $-0.026^{* *}$ & 0.012 & 0.032 & 0.015 & 0.082 & 0.847 \\
\hline SE & $b_{4}$ & 0.010 & 0.014 & 0.458 & 0.059 & 0.092 & 0.516 \\
\hline ASSET & $b_{5}$ & 0.024 & 0.015 & 0.121 & $0.214^{* * *}$ & 0.113 & 0.058 \\
\hline LOAN & $b_{6}$ & $-0.023^{* * *}$ & 0.012 & 0.066 & $-0.154^{* *}$ & 0.068 & 0.024 \\
\hline RISK & $b_{7}$ & $0.058^{*}$ & 0.013 & 0.000 & $0.121^{*}$ & 0.028 & 0.000 \\
\hline AGE & $b_{8}$ & 0.001 & 0.001 & 0.818 & -0.002 & 0.001 & 0.120 \\
\hline GDP & $b_{9}$ & $0.001^{*}$ & 0.001 & 0.000 & -0.001 & 0.001 & 0.718 \\
\hline & $\mathrm{R}^{2}$ & 0.268 & & & 0.035 & & \\
\hline & üzeltilmiş $\mathrm{R}^{2}$ & 0.199 & & & 0.019 & & \\
\hline & F İstatistiği & $3.934^{*}$ & & 0.000 & $2.156^{* *}$ & & 0.023 \\
\hline
\end{tabular}

Not: ${ }^{* * *},{ }^{* * *}$ sırasıyla \%1, \%5 ve \%10 önem düzeyinde katsayının anlamlı olduğunu göstermektedir.

ROE değişkenin bağımlı değişken olduğu modelde ise ilgili katsayılardan sadece $b_{2}$ katsayısı \%10 önem düzeyinde istatistiki açıdan anlamlı ve pozitif işaretli olarak tespit edilmiştir (1.415). Yani, piyasa payının artması halinde karlılık da artmaktadır. Bu sonuç, RMP hipotezinin kısmen geçerli olduğunu göstermektedir. Kontrol değişkenlerinden ASSET ve RISK değişkenleri ile ROE arasında pozitif, LOAN değişkeni ile ROE arasında negatif yönde ve farklı önem düzeylerine göre istatistiki bakımdan anlamlı ilişkiler olduğu belirlenmiştir. 
Tablo 9'da 2 ve 3 no.lu eşitliklerin tahmin sonuçları görülmektedir. 2 no.lu eşitlikte yer alan $a_{3}$ katsayısı sıfıra oldukça yakın olmasına karşılık $a_{2}$ katsayısı negatif işaretli tespit edildiği için RMP hipotezinin geçerli olmadığı söylenebilir.

Benzer biçimde 3 no.lu eşitlikteki $b_{3}$ katsayısı sıfıra oldukça yakın olmasına rağmen $b_{2}$ katsayısı negatif işaretli olduğundan SCP hipotezinin de geçerli olmadığı görülmektedir. Hem $a_{2}$ ve hem de $b_{2}$ katsayıları negatif işaretli oldukları için (yani, teknik etkinliğin artması piyasa payını ve yoğunlaşmayı azaltmakta) ESX hipotezi de geçerli değildir. Ayrıca $a_{3 \text { ve }} b_{3}$ katsayıları istatiski açıdan anlamlı ve sıfıra oldukça yakın olmalarına rağmen pozitif işaretli oldukları için (yani, ölçek etkinliğinin artması piyasa payını ve yoğunlaşmayı arttırmakta) ESS hipotezi kısmen geçerlidir.

Tablo 9: Piyasa Payı-Yoğunlaşma ile Teknik Etkinlik ve Ölçek Etkinliği İçin Regresyon Sonuçları

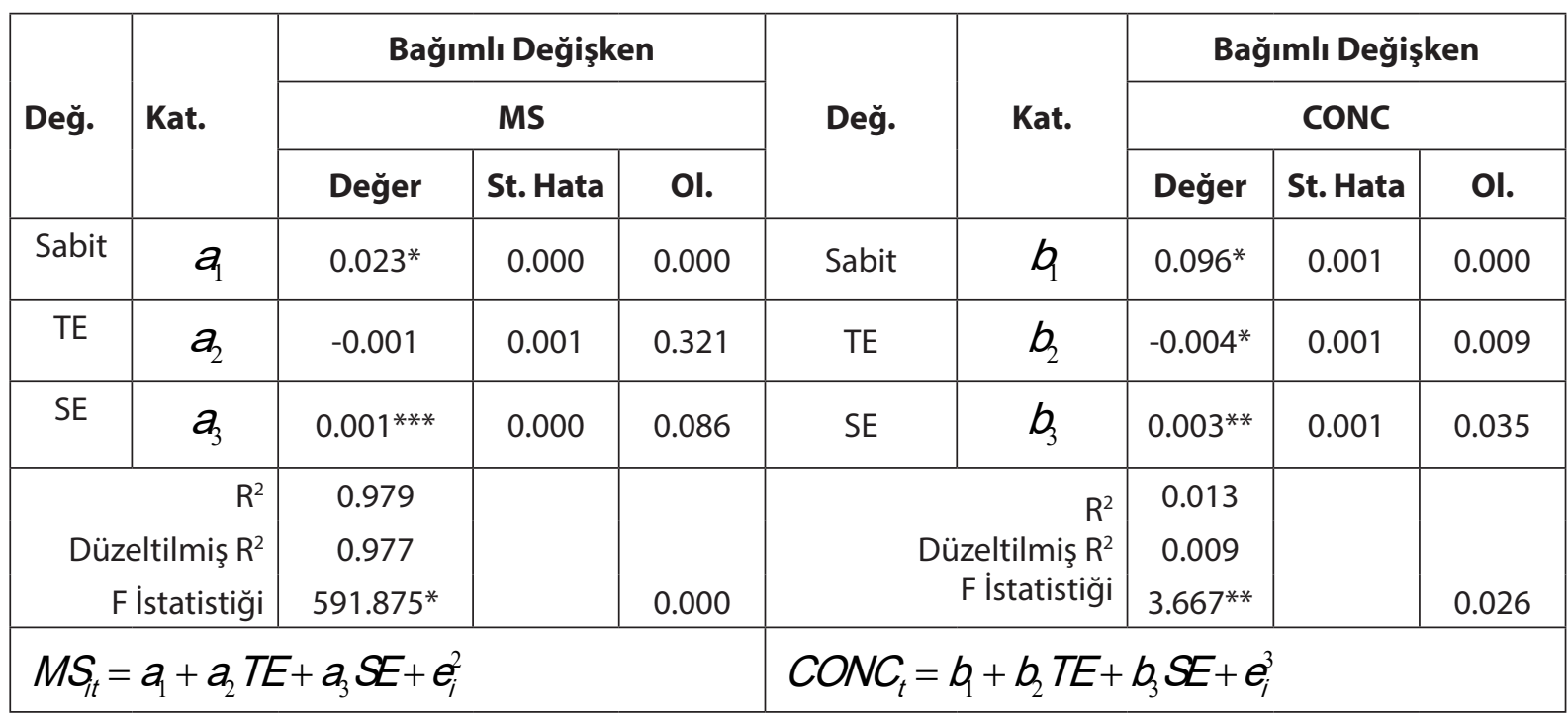

Not: ${ }^{* * *},{ }^{* * *}$ sırasıyla $\% 1, \% 5$ ve \%10 önem düzeyinde katsayının anlamlı olduğunu göstermektedir.

Son olarak tablo $10^{\prime}$ da 4 ve 5 no.lu eşitliklerden elde edilen tahmin sonuçları verilmektedir. Her iki eşitlik için R2 değerleri oldukça yüksektir. Yani bağımsız değişkenler bağımlı değişkeni oldukça iyi bir biçimde açıklamaktadır. Benzer biçimde $F$ istatistiklerine ait olasılık değerleri de sıfıra oldukça yakın olduklarından her iki modelin bir bütün olarak anlamlı olduğunu söylemek mümkündür. 4 no.lu

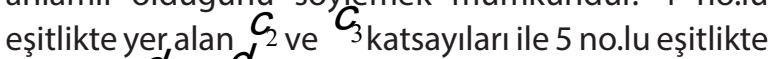
bulunan $d_{2 \text { ve }} d_{3 \text { katsayılarının hepsi istatistikiaçıdan }}$ anlamlı ve sıfırdan küçük olarak tespit edilmiştir. Yani, yoğunlaşma ve piyasa payının artması hem teknik ekinliği ve hem de ölçek etkinliğini azaltmaktadır.
Buna göre, QL hipotezinin güçlü bir biçimde geçerli olduğunu söylemek mümkündür. QL hipotezi, herhangi bir sebeple elde edilmiş piyasa gücünün, firmaya tam rekabete göre daha yüksek fiyatlama imkânı sunması ve böylece maliyet minimizasyonu güdüsünün zayıflaması olarak tanımlanabilir. Bu bağlamda QL hipotezi firmaların performanslarının illaki etkinlikten kaynaklanmadığını, elde edilmiş yüksek piyasa payının piyasa gücüne ve etkinsizliğe yol açabileceğini ve bu etkinsizliğin ise tekrar piyasa yapısını etkileyebileceğini ileri sürmektedir (Demirel ve Hatırlı, 2014: 100). 
Tablo 10: Teknik Etkinlik-Ölçek Etkinliği ile Piyasa Payı, Yoğunlaşma ve Kontrol Değişkenleri İçin Regresyon Sonuçları

\begin{tabular}{|c|c|c|c|c|c|c|c|c|c|}
\hline \multirow{3}{*}{ Değ. } & \multirow{3}{*}{ Kat. } & \multicolumn{3}{|c|}{ Bağımlı Değişken } & \multirow{3}{*}{ Değ. } & \multirow{3}{*}{ Kat. } & \multirow{2}{*}{\multicolumn{3}{|c|}{$\begin{array}{c}\text { Bağımlı Değişken } \\
\text { SE }\end{array}$}} \\
\hline & & \multicolumn{3}{|c|}{ TE } & & & & & \\
\hline & & Değer & St. Hata & Ol. & & & Değer & St. Hata & Ol. \\
\hline Sabit & $G$ & $1.020^{*}$ & 0.227 & 0.000 & Sabit & $d_{1}$ & $0.829^{*}$ & 0.320 & 0.010 \\
\hline CONC & $c_{2}$ & $-2.932^{* * *}$ & 1.619 & 0.070 & CONC & $d_{2}$ & $-0.246^{* *}$ & 2.431 & 0.019 \\
\hline MS & $c_{3}$ & $-1.605^{* * *}$ & 0.879 & 0.068 & MS & $d_{3}$ & $-1.400^{*}$ & 0.052 & 0.007 \\
\hline ASSET & $C_{4}$ & -0.039 & 0.033 & 0.235 & ASSET & $d_{4}$ & -0.044 & 0.058 & 0.452 \\
\hline LOAN & $c_{5}$ & $0.186^{*}$ & 0.020 & 0.000 & LOAN & $d_{5}$ & $0.212^{*}$ & 0.047 & 0.000 \\
\hline RISK & $c_{6}$ & $0.126^{*}$ & 0.015 & 0.000 & RISK & $d_{6}$ & $0.099 *$ & 0.036 & 0.006 \\
\hline AGE & $c$ & $-0.016^{*}$ & 0.002 & 0.000 & AGE & $d_{7}$ & $-0.016^{*}$ & 0.004 & 0.001 \\
\hline GDP & $c_{8}$ & $-0.005^{*}$ & 0.001 & 0.000 & GDP & $d_{8}$ & $-0.003^{*}$ & 0.001 & 0.008 \\
\hline & $R^{2}$ & 0.855 & & & & $\mathrm{R}^{2}$ & 0.808 & & \\
\hline Düz & Imiş $R^{2}$ & 0.842 & & & & Düzeltilmiş $\mathrm{R}^{2}$ & 0.791 & & \\
\hline & atistiği & $66.405^{*}$ & & 0.000 & & F İstatistiği & $47.489^{*}$ & & 0.000 \\
\hline $\begin{array}{l}T E_{i t}= \\
S E_{i t}=\end{array}$ & CO & $\begin{array}{l}+c_{3} M \\
+d_{3} M\end{array}$ & $\begin{array}{l}C_{4} A S \\
d_{4} A\end{array}$ & + & $\begin{array}{l}4 N_{i t}+ \\
P A N_{i t}\end{array}$ & $\begin{array}{l}R / S K_{i t}+c_{7} \\
d_{6} R / K_{i t}+c\end{array}$ & $\begin{array}{l}4 G E_{i t}+ \\
{ }_{7} A G E_{i t}\end{array}$ & $\begin{array}{l}G D P_{t}+ \\
d_{8} G D P_{t}\end{array}$ & \\
\hline
\end{tabular}

Not: ${ }^{*}{ }^{* *},{ }^{* * *}$ sırasıyla \%1, \%5 ve \%10 önem düzeyinde katsayının anlamlı olduğunu göstermektedir.

4 ve 5 no.lu eşitliklerde bulunan kontrol değişkenlerinden LOAN ve RISK bağımlı değişkenleri sırasıyla TE ve SE'yi istatistiki açıdan \%1 önem düzeyinde anlamlı ve olumlu yönde etkilerken AGE ve GDP değişkenleri ise bağımlı değişkenleri istatistiki bakımdan \%1 önem düzeyinde anlamlı ve olumsuz yönde etkilemektedir.

\section{SONUÇ}

Bu çalışma, 2001-2014 döneminde Türk bankacılık endüstrisinin piyasa yapısı ve karlılık arasındaki ilişkiyi tespit etmeyi amaçlamaktadır. Berger (1998) tarafından ifade edilen beş ayrı hipotezi test etmeyi amaçlayan model endüstriye uygulanmıştır.

Çalışmada bu hipotezleri test edebilmek için 14 yıllık periyotta 42 bankaya ait toplam 588 gözlem yardımıyla genelleştirilmiş en küçük kareler panel veri yönteminden faydalanılmıştır.

Sonuç olarak, ilgili dönemde bankacılık endüstrisi için yapı-davranış-performans (SCP), göreli-piyasa- gücü (RMP) ve etkin yapı: ölçek etkinliği (ESS) hipotezlerinin kısmen geçerli olduğu ve rahat yaşam (QL) hipotezinin ise güçlü bir biçimde geçerli olduğu tespit edilmiştir. Yani, bankacılık endüstrisindeki yoğunlaşmanın kısmen daha yüksek karlara sebep olduğu ve endüstrideki daha büyük piyasa paylarının kısmen daha yüksek kara yol açtığı ve daha büyük bankaların ise kısmen daha yüksek kar elde etikleri söylenebilir. Ayrıca, güçlü bir şekilde bankacılık endüstrisinde piyasa yapısı ve banka performansı arasında bir ilişkinin bulunmadığını yani banka yönetimlerinin fiyat düzenlemelerinin gelirlerini arttırabileceği ama daha yüksek etkinsizlik düzeyinde bunun bankaların daha yüksek karlarına yol açmayacağı belirlenmiştir.

2001 yılı sonrası, Türk bankacılık endüstrisi için ciddi yapısal değişimlerin gerçekleştiği bir dönemdir. Konuyla ilgili literatürdeki diğer çalışmalar ile bu çalışma arasında göze çarpan temel farklılık teknik etkinlik ile karlıık arasında negatif yönde bir ilişkinin tespit edilmiş olmasıdır. 
Söz konusu bulgulardan hareketle, düzenleme görevini üstlenen kurumların bankaların etkinliğini arttıracak politikalardan (firma birleşmelerinin teşvik edilmesi vb.) ziyade bankacılık endüstrisinde ortaya çıkan yoğunlaşmayı azaltıı tedbirler alması gerektiğini ifade etmek mümkündür.

Çalışmada elde edilen sonuçlar, inceleme döneminde değerlendirilen bankalardan elde edilebilen veriler, kullanılan değişkenler ve analiz yöntemi ile sınırı olmaktadır. Farklı dönem, değişkenler ve yöntemlerin kullanılması analiz sonuçlarının farklılaşmasına yol açabilir. Endüstrinin piyasa yapısı ve karlılığı arasındaki ilişkiler, farklı değişkenler, zaman periyodu ve yöntemlerle de tespit edilebilir.

\section{KAYNAKLAR}

Abreu, M. ve Mendes, V. (2001) "Commercial Bank Interest Margins and Profitability: Evidence from Some EU Countries" The Proceedings of the PanEuropean Conference, The IEFS-UK\&University of Macedonia Economic\&Social Sciences, Thessaloniki, Greece, May 17-20, Thessaloniki.

Afşar, M. (2011) "Küresel Kriz ve Türk Bankacılık Sektörüne Yansımaları" Eskişehir Osmangazi Üniversitesi IiBF Dergisi, 6(2): 143-171.

Al-Jafari, M. K. ve Alchami, M. (2014) "Determinants of Bank Profitability: Evidence from Syria" Journal of Applied Finance \& Banking, 4(1): 17-45.

Al-Muharrami, S. ve Matthews, K. (2009) "Market Power versus Efficient-Structure in Arab GCC Banking" Cardiff Economics Working Papers, No: 2009/7.

Atemkeng, T. ve Nzongang, J. (2006) “Market Structure and Profitability Performance in the Banking Industry of CFA Countries: The Case of Commercial Banks in Cameroon" Journal of Sustainable Development in Africa, 8(2): 1-14.

Athanasoglou, P. P., Delis, M. D. ve Staikouras, C. K. (2006) "Determinants of Bank Profitability in the South Eastern European Region" Bank of Greece Working Paper, 47.

Athanasoglou, P. P., Brissimis, S. N. ve Delis, M. D. (2008) "Bank-Specific, Industry-Specific and Macroeconomic Determinants of Bank Profitability" International Financial Markets, Institutions\&Money, 18: 121-136.

Ayadi, I. ve Ellouze, A. (2013) "Market Structure and Performance of Tunisian Banks" International Journal of Economics and Financial Issues, 3(2): 345-354.

Ayaydın, H. ve Karakaya, A. (2014) "The Effect of Bank Capital on Profitability and Risk in Turkish Banking" International Journal of Business and Social Science, 5(1): 252-271.

Banker, R. D. (1992) "Estimation of Returns to Scale Using Data Envelopment Analysis" European Journal of Operational Research, 62(1): 74-84.
Beck, T., Demirgüç Kunt, A. ve Levine, R. (2003) "Bank Concentration and Crises" National Bureau of Economic Research Working Paper, 9921.

Behname, M. (2012) "The Compare of Concentration and Efficiency in Banking Industry: Evidence from the OPEC Countries" Eurasian Journal of Business and Economics, 5(10): 15-24.

Bektas, E. (2006) "Test of Market Structure and Profitability in Liberalizing the Deposit Market: The Case of North Cyprus" Problems and Perspectives in Management, 4(2): 62-67.

Berger, A. N. ve Hannan, T. H. (1989) "The PriceConcentration Relationship in Banking" The Review of Economics and Statistics, 71(2): 291-299.

Berger, A. N. (1995) “The Profit-Structure Relationship in Banking-Tests of Market-Power and EfficientStructure Hypotheses" Journal of Money, Credit, and Banking, 27(2): 404-431.

Berger, A. N. ve Hannan, T. H. (1997) “Using Efficiency Measures to Distinguish Among Alternative Explanations of the Structure-Performance Relationship in Banking" Managerial Finance, 23: 6-31.

Berger, A. N. ve Hannan, T. H. (1998) "The Efficiency Cost of Market Power in the Banking Industry: A Test of The 'Quiet Life' and Related Hypotheses" Review of Economics and Statistics, 80: 454-465.

Charnes, A., Cooper, W. W., Rhodes, E. (1978) "Measuring the Efficiency of Decision Making Units" European Journal of Operational Research, 2: 429-444.

Charnes, A., Cooper, W. W., Lewin, A. Y., Seiford, L. M. (1997) Data Envelopment Analysis: Theory, Methodology and Applications Kluwer Academic Publishers, Massachusetts.

Chirwa, E. W. (2003) "Determinants of Commercial Banks' Profitability in Malawi: A Cointegration Approach" Applied Financial Economics, 13: 565-571.

Chortareas, G., Garza Garcia, J. G. ve Girardone, C. (2009) "Banking Sector Performance in Latin 
America: Market Power versus Efficiency" University of The West of England, Department of Economics, Discussion Papers, 0905.

Claeys, S. ve Vennet, R. V. (2008) "Determinants of Bank Interest Margins in Central and Eastern Europe: A Comparison with the West" Economic Systems, 32(2): 197-216.

Cooper, W. W., Seiford, L. M., Tone, K. (2007) DEA: A Comprehensive Text with Models, Applications, References and DEA-Solver Software Kluwer Publication, Boston.

Deltuvaite, V. (2009) “The Profit-Structure Relationship in Banking Industry: An Empirical Analysis"In Changes in Social and Business Environment: proceedings of the 3rd international conference, Kaunas University of Technology Panevezys Institute, November 4-5, Lithuania.

Deltuvaite, V. (2010) "The Market StructureProfitability Relationship in Banking: Test of the Structure-Conduct-Performance (SCP) Hypothesis in the OECD Countries" Socialiniai Mokslai, 88(41): 50-62.

Demirel, O. ve Hatırlı, S. A. (2014) "Teorik Pazar Gücü Modelleri" Süleyman Demirel Üniversitesi Vizyoner Dergisi, 5(10): 96-121.

Demirgüç Kunt, A. ve Huizinga, H. (1999) "Determinants of Commercial Bank Interest Margins and Profitability: Some International Evidence" World Bank Policy Research Working Paper, 1900.

De Guevara, J. F., Maudos, J. ve Perez, F. (2005) "Market Power in European Banking Sector" Journal of Financial Services Research, 27(2): 109-137.

Denizer, C. (1997) "The Effects of Financial Liberalization and New Bank Entry on Market Structure and Competition in Turkey" Development Research Group, World Bank.

Dietrich, A. ve Wanzenried, G. (2014) "The Determinants of Commercial Banking Profitability in Low-,Middle-, and High-Income Countries" The Quarterly Review of Economics and Finance, 54: 337354.

Ekren, N. ve Emiral, F. (2002) "Türk Bankacılık Sisteminde Etkinlik Analizi (Veri Zarflama Analizi Uygulaması)" Active Bankacılık ve Finans Dergisi, 24: 1-32.

Evanoff, D. D. ve Fortier, D. L. (1988) "Reevaluation of the Structure-Conduct-Performance Paradigm in Banking" Journal of Financial Services Research, 1: 277294.
Flamini, V., McDonald, C. ve Schumacher, L. (2009) "The Determinants of Commercial Bank Profitability in Sub-Saharan Africa" IMF Working Papers, 09/15.

Fu, X. M. ve Heffernan, S. (2009) “The Effects of Reform on China's Bank Structure and Performance" Journal of Banking\&Finance, 33: 39-52.

Gajurel, D. P. ve Pradhan, R. S. (2011) "StructurePerformance Relation in Nepalese Banking Industry" International Proceedings of Economic Development and Research, 2: 25-31.

Garza-Garcia, J. G. (2012) “Does Market Power Influence Bank Profits in Mexico? A Study on Market Power and Efficiency" Applied Financial Economics, 22: 21-32.

Goldberg, L. G. ve Rai, A. (1996) "The StructurePerformance Relationship for European Banking" Journal of Banking and Finance, 20: 745-771.

Gonzalez, F. (2005) "Determinants of Bank Market Structure: Efficiency and Political Economy Variables" Fundacion de las Cajas de Ahorros Working Paper, 219.

Gonzalez, F. (2009) "Determinants of Bank-Market Structure: Efficiency and Political Economy Variables" Journal of Money, Credit and Banking, 41(4): 735-754.

Günalp, B. ve Çelik, T. (2004) "Türk Bankacılık Sektöründe Piyasa Yapısı ve Performans Illişkilerinin Etkinlik İçin Doğrudan Bir Ölçüt Kullanılarak Test Edilmesi" Gazi Üniversitesi Iktisadi ve Idari Bilimler Fakültesi Dergisi, 6(3): 31-57.

İnan, A. (2000) “Banka Etkinliğinin Ölçülmesi ve Düşük Enflasyon Sürecinde Bankacılıkta Etkinlik" Bankacılık Dergisi, 34: 82-97.

Jansen, D. ve de Haan, J. (2003) "Increasing Concentration in European Banking: A MacroLevel Analysis" De Nederlandsche Bank Research Memorandum Paper, 743.

Jeon, Y. ve Miller, S. M. (2005) "Bank Performance: Market Power or Efficient Structure?" University of Connecticut, Economics Working Paper, 2005-23.

Kamau, A. ve Were, M. (2013) "What Drives Banking Sector Performance in Kenya?" Global Business and Economics Research Journal, 2(4): 45-59.

Kalirajan, K. ve Shand, R. T. (1999) “Frontier Production Functions and Technical Efficiency Measures" Journal of Economic Surveys, 13(2): 149-172.

Kasman, A. (2001) "The Profit-Structure Relationship in the Turkish Banking Industry using Direct Measures of Efficiency" Ege Akademik Bakış Dergisi 1(1): 141-164. 
Kasman, A., Kasman, S. ve Turgutlu, E. (2011) "Testing Profit and Structure Relationship in the European Banking Markets Using Efficiency Measures" The Developing Economies, 49(4): 404-428.

Martin, S. (1988) Industrial Economics: Economic Analysis and Public Policy New York, MacMillan Publishing Company.

Maudos, J. (1998) "Market Structure and Performance in Spanish Banking Using A Direct Measure of Efficiency" Applied Financial Economics, 8: 191-200.

Mensi S. ve Zouari, A. (2010) “Efficient Structure versus Market Power: Theories and Empirical Evidence" International Journal of Economics and Finance, 2(4): 151-166.

Mensi S. ve Zouari, A. (2011) "Banking Industry, Market Structure and Efficiency: The Revisited Model to Intermediary Hypotheses" International Journal of Economics and Research, 2(1): 23-36.

Mirzaei, A., Liu, G. ve Moore, T. (2011) “Does Market Structure Matter on Banks' Profitability and Stability? Emerging versus Advanced Economies" Brunel University, Economics and Finance Working Paper Series, 11-12.

Molyneux, P. ve Thornton, J. (1992) "Determinants of European Bank Profitability: A Note" Journal of Banking and Finance, 16(6): 1173-1178.

Molyneux, P. ve Forbes, W. (1995) "Market Structure and Performance in European Banking" Applied Economics, 27(2): 155-159.

Nerlove, Marc (2005) Essays in Panel Data Econometrics Cambridge, Cambridge University Press.

Okumuş, H. Ş. (2002) “Market Structure and Efficiency as Determinants of Profitability in the Turkish Banking Industry" Yapı Kredi Economic Review, 13: 65-88.

Osuagwu, E. (2014)“Determinants of Bank Profitability in Nigeria" International Journal of Economics and Finance, 6(12): 46-63.

Özcan, A. ve Çiftçi, C. (2015) "Türkiye'de Mevduat Bankacılığında Yoğunlaşma ve Karlılık İlişkisi (20062013 Dönemi)" Niğde Üniversitesi Iktisadi ve Idari Bilimler Fakültesi Dergisi, 8(3): 1-12.
Park, K. H. ve Weber, W. L. (2006) "Profitability of Korean Banks: Test of Market Structure versus Efficient Structure" Journal of Economics and Business, 58: 222239.

Pasiouras, F. ve Kosmidou, K. (2007) "Factors Influencing the Profitability of Domestic and Foreign Commercial Banks in the European Union" Research in International Business and Finance, 21(2): 222-237.

Pepall, L., Richards, D. J.,ve Norman, G. (2005) Industrial Organization Contemporary Theory\&Practice Canada, Thomson South Western.

Punt, L. W. ve van Rooij, M. C. J. (1999) "The ProfitStructure Relationship, Efficiency and Mergers in the European Banking Industry: an Empirical Assessment" Netherlands Central Bank, WO Research Memoranda, 604.

Sarıgül, H. (2013) "Concentration and Profitability in Turkish Banking Industry" Proceedings of the 11th Eurasia Business and Economics Society Conference (EBES), September 12-14, Ekaterinburg.

Seelanatha, L. (2010) "Market Structure, Efficiency and Performance of Banking Industry in Sri Lanka" Banks and Bank Systems, 5(1): 20-31.

Smirlock, M. (1985) "Evidence on the (Non) Relationship between Concentration and Profitability in Banking" Journal of Money, Credit and Banking, 17(1): 69-83.

Staikouras, C. K. ve Wood, G. E. (2004) "The Determinants of European Bank Profitability" International Business\&Economics Research Journal, 3(6): 57-68.

Tregenna, F. (2009) "The Fat Years: The Structure and Profitability of the US Banking Sector in the pre-Crisis Period" Cambridge Journal of Economics, 33: 609-632.

Sueyoshi, T. (1992) "Measuring Technical, Allocative and Overall Efficiencies Using a DEA Algorithm" Journal of the Operational Research Society, 43(2): 141155.

Ye, Q., Xu, Z. ve Fang, D. (2012) “Market Structure, Performance, and Efficiency of the Chinese Banking Sector" Econ Change Restruct, 45: 337-358. 
